\title{
Temperature and salinity as interacting drivers of species richness of planktonic rotifers in Turkish continental waters
}

\author{
Murat KAYA*, Diego FONTANETO ${ }^{1,2)}$, Hendrik SEGERS ${ }^{3)}$ and Ahmet ALTINDAĞ $\breve{G}^{4)}$ \\ Aksaray University, Faculty of Science and Letters, Department of Biology, 68100, Aksaray, Turkey \\ ${ }^{1)}$ Swedish Museum of Natural History, Department of Invertebrate Zoology, Frescativägen 40, 10405 Stockholm, Sweden \\ ${ }^{2)}$ Imperial College London, Division of Biology, Silwood Park Campus, Ascot Berkshire, SL57PY, United Kingdom \\ ${ }^{3)}$ Royal Belgian Institute of Natural Sciences, Freshwater Biology, Vautierstraat 29, B-1000, Brussels, Belgium \\ 4) Ankara University, Faculty of Science, Department of Biology, Tandoğan, Ankara, 06100, Turkey \\ *e-mail corresponding author: muratkaya3806@yahoo.com
}

\begin{abstract}
Salinity and temperature are known to be important factors driving species richness and species composition in inland waters, but their effect and interaction are still not completely clear. In this paper we examine their interaction on species richness and species composition of planktonic rotifers in Turkey, controlling for other confounding effects. Eighty-four species of Rotifera belonging to 32 genera were recorded from eight sampling sites in Develi Plain (Middle Anatolia, Kayseri, Turkey), collecting repeated samples in different seasons (April, July, October and December 2007), and measuring water parameters (electrical conductivity, $\mathrm{pH}$ and temperature). Generalised Linear Models and Mixed Effect Models were used to disentangle the effect of the environmental parameters on species richness and composition. Temperature positively affected species richness as expected from previous studies. Whereas this effect was clear in the freshwater habitats (less than $1000 \mu \mathrm{S} \mathrm{cm}{ }^{-1}$ ), it was not observed at all at higher salinities. Surprisingly, species richness significantly increased with salinity in subsaline waters between 1000 and $6000 \mu \mathrm{S}$ $\mathrm{cm}^{-1}$. Species composition varied among sampling sites (accounting for $36.2 \%$ of total variation), but no other factors were found to be involved.
\end{abstract}

Key words: diversity, Rotifera, salinity, temperature

\section{INTRODUCTION}

In both saline and freshwater continental zooplankton, species richness is affected by environmental parameters, mainly temperature and salinity (Williams 1998). A positive correlation between temperature and species richness in freshwater has been described for aquatic invertebrates in general (Friberg et al. 2001), and for zooplankton in particular (Hessen et al. 2007; Kaya \& Altındağ 2007). Salinity is another important factor affecting species richness in continental water bodies (Lancaster \& Scudder 1987; Williams et al. 1990; Derry et al. 2003), with inland saline systems hosting less species than freshwater bodies (Hart et al. 1998; Schallenberg et al. 2003; Toumi et al. 2005; Shiel et al. 2006). Salinity of inland waters may increase due to evaporation; thus, a positive correlation between salinity and temperature should be expected. Such positive correlation is not coherent with the opposite effects of these variables on species richness and more studies addressing this interaction are needed.

Number of species and species composition of zooplankton are known to be affected not only by temperature and salinity but also by other parameters, such as habitat type (Muirhead et al. 2006), trophic state and water turbidity (Duggan et al. 2002), and total phosphorus (Jeppesen et al. 2000). Other unmeasured variables differing between sampling site may affect species composition as well, and for zooplankton species assemblages such local effect is well known (Cottenie et al. 2001; De Bie et al. 2008; Dodson et al. 2009).

The aim of this study is to examine the effect of temperature and salinity on species richness and composition of rotifer communities in inland fresh and saline waters in a biogeographically uniform area. Rotifers were used as a test case because they are globally diverse, with more than 2000 species known to date (Segers 2007); they can be extremely rich locally, with over 100 species recorded from one single water body (Segers \& Dumont 1995), and they occur in fresh and saline water, with few species able to tolerate changes in salinity (Fontaneto et al. 2006, 2008; Segers 2007). Rotifer species richness is already known to conform to the general trend with species richness negatively related to salinity (Walsh et al. 2008), and positively related to temperature (Matsubara 1993; Castro et al. 2005), but such relationships have never been analyzed together in detail for rotifers, and controlling for other confounding effects.

\section{MATERIALS AND METHODS \\ 2.1. Sample collection}

The study was carried out in eight water bodies in Develi Plain (Middle Anatolia, Kayseri, Turkey, Fig. 1, 


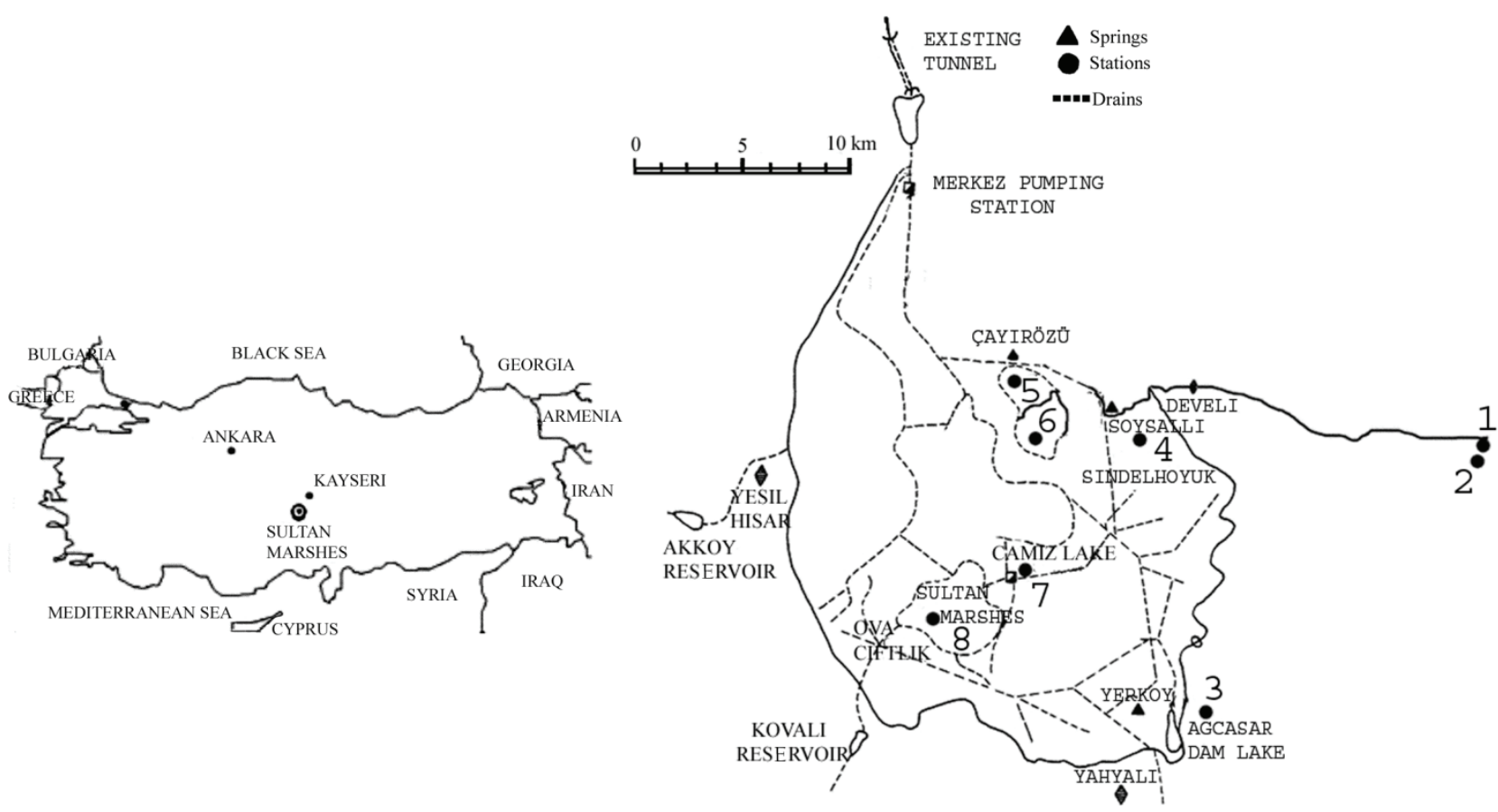

Fig. 1. Map of sampling localities. 1. Zamantı River, 2. Homurlu Stream, 3. Ağcaşar Dam Lake, 4. Soysallı Pond, 5. Çayı̈özü Pond, 6. Lake Söbe, 7. Lake Camı, 8. Sultan Marshes.

Tab. 1), collecting repeated samples in different seasons (April, July, October and December 2007). Water bodies were from 1 to $48 \mathrm{~km}$ far away from each other. For each water body four different samples were collected, $50 \mathrm{~m}$ apart one from the other, along a linear transect of $150 \mathrm{~m}$. Samples were obtained with a plankton net $55 \mu \mathrm{m}$ mesh size (Wallace et al. 2006), collecting horizontal hauls of approximately $5 \mathrm{~m}$, in areas with depth between 0.4 and $1.5 \mathrm{~m}$, at least $5 \mathrm{~m}$ from the bank. Samples from each water body were merged and poured in a single $500 \mathrm{~mL}$ bottle and preserved in $4 \%$ formaldehyde solution.

All sampled localities were stagnant waters; six of them were true ponds and lakes (A ğcaşar Dam Lake, Soysallı Pond, Çayı̈özü Pond, Lake Söbe, Lake Camız and Sultan Marshes centre); for the two lotic systems (Zamantı River and Homurlu Stream), samples were taken from stagnant parts of the water bodies.

\subsection{Environmental variables}

We measured three variables, temperature, $\mathrm{pH}$ and electrical conductivity. Parameters were measured in the same areas where samples were collected, at about half of the depth of the water column.

Electrical conductivity was measured in $\mu \mathrm{S} \mathrm{cm}^{-1}$ and used as a proxy of salinity. Following the system by Hammer et al. (1983), we considered water bodies as freshwater (FW, with electrical conductivity lower than $1000 \mu \mathrm{S} \mathrm{cm} \mathrm{cm}^{-1}$, i.e. $0-0.5 \mathrm{~g} \mathrm{~L}^{-1}$ of total dissolved salts, TDS), subsaline (SS, electrical conductivity 1000 to
$6000 \mu \mathrm{S} \mathrm{cm} \mathrm{cm}^{-1}$, i.e. $0.5-3 \mathrm{~g} \mathrm{~L}^{-1} \mathrm{TDS}$ ), hyposaline (HS, electrical conductivity 6000 to $40,000 \mu \mathrm{S} \mathrm{cm}^{-1}$, i.e. 3-20 $\mathrm{g} \mathrm{L}^{-1} \mathrm{TDS}$ ); none of the salinity values we observed in the field exceeded the latter class.

\subsection{Species identification}

We used a Leica DMLS microscope (40 to $1000 \times$ ) for identification and drawing of the species. Taxonomic features of rotifer jaws (trophi) were observed after dissolving the soft body parts in diluted $\mathrm{NaOCl}$ (Segers 2004). Scanning electron microscopy (SEM) preparations were obtained following the procedure by De Smet (1998). SEM observation was performed using a JEOL JSM-60 60 LV on material sputter-coated with a Polaron SC 502.

\subsection{Species richness}

We calculated species richness as the total number of species found in each season for each water body.

First, we tested the hypothesis that species richness in freshwater (FW) is higher than in saline waters (SS + HS). We used a Generalised Linear Model (GLM), assuming a quasi-poisson distribution because of overdispersion of data. Then, to disentangle the effects of the measured environmental variables on species richness, we performed a Linear Mixed Effect Model (LMEM) for Repeated Measures, including sampling site as a random effect. This was performed with the $R$ 2.5.1 ( $R$ Development Core Team 2007) function lme from the package nlme (http://cran.r-project.org/web/ 
Tab. 1. Sampling localities and water parameters. EC is Electrical Conductivity; values of EC are labeled in three salinity categories according to Hammer et al. (1983): FW, freshwater; SS, subsaline; HS, hyposaline. WT is Water Temperature. SR is Species Richness. Alt is Altitude.

\begin{tabular}{|c|c|c|c|c|c|c|c|}
\hline ID & Water Body & $\mathrm{pH}$ & $\mathrm{EC}\left(\mu \mathrm{S} \mathrm{cm}^{-1}\right)$ & WT $\left({ }^{\circ} \mathrm{C}\right)$ & SR & Alt (m) & Coordinates \\
\hline 1 & Zamanti River & & & & & \multirow[t]{5}{*}{1297} & \multirow[t]{5}{*}{$38^{\circ} 13^{\prime} 12.07^{\prime \prime} \mathrm{N} ; 35^{\circ} 47^{\prime} 02.89^{\prime \prime} \mathrm{E}$} \\
\hline $1 . \mathrm{A}$ & April & 7.45 & $480^{\mathrm{FW}}$ & 11.7 & 8 & & \\
\hline $1 . \mathrm{J}$ & July & 7.59 & $376^{\mathrm{FW}}$ & 19.7 & 26 & & \\
\hline 1.0 & October & 7.37 & $508^{\mathrm{FW}}$ & 13.0 & 14 & & \\
\hline 1.D & December & 7.90 & $489^{\mathrm{FW}}$ & 5.8 & 3 & & \\
\hline 2 & Homurlu Stream & & & & & \multirow[t]{5}{*}{1311} & \multirow[t]{5}{*}{$38^{\circ} 12^{\prime} 31.22^{\prime \prime} \mathrm{N} 35^{\circ} 47^{\prime} 11.04^{\prime \prime} \mathrm{E}$} \\
\hline 2.A & April & 8.85 & $190^{\mathrm{FW}}$ & 14.3 & 14 & & \\
\hline $2 . \mathrm{J}$ & July & 7.77 & $296^{\mathrm{FW}}$ & 19.1 & 9 & & \\
\hline 2.0 & October & 8.44 & $289^{\mathrm{FW}}$ & 14.6 & 8 & & \\
\hline 2.D & December & $\begin{array}{l}0.44 \\
9.36\end{array}$ & $223^{\mathrm{FW}}$ & 3.6 & 7 & & \\
\hline 3 & Ağcaşar Dam Lake & & & & & \multirow[t]{5}{*}{1109} & \multirow[t]{5}{*}{$38^{\circ} 10^{\prime} 42.01^{\prime \prime} \mathrm{N} ; 35^{\circ} 23^{\prime} 33.05^{\prime \prime} \mathrm{E}$} \\
\hline $3 . \mathrm{A}$ & April & 8.90 & $2700^{\mathrm{SS}}$ & 12.0 & 6 & & \\
\hline $3 . \mathrm{J}$ & July & 8.49 & $2540^{\mathrm{SS}}$ & 25.8 & 9 & & \\
\hline 3.0 & October & 8.87 & $376^{\mathrm{FW}}$ & 16.2 & 13 & & \\
\hline $3 . \mathrm{D}$ & December & 8.76 & $375^{\mathrm{FW}}$ & 3.8 & 2 & & \\
\hline 4 & Soysalli Pond & & & & & \multirow[t]{5}{*}{1079} & \multirow[t]{5}{*}{$38^{\circ} 23^{\prime} 18.09^{\prime \prime N} ; 35^{\circ} 21^{\prime} 43.73^{\prime \prime} \mathrm{E}$} \\
\hline 4.A & April & 6.78 & $190^{\mathrm{FW}}$ & 11.9 & 14 & & \\
\hline 4.J & July & 6.87 & $129^{\mathrm{FW}}$ & 13.8 & 12 & & \\
\hline 4.0 & October & 7.10 & $130^{\mathrm{FW}}$ & 13.5 & 9 & & \\
\hline 4.D & December & 6.60 & $126^{\mathrm{FW}}$ & 8.8 & 1 & & \\
\hline 5 & Çayırözü Pond & & & & & \multirow[t]{5}{*}{1074} & \multirow[t]{5}{*}{$38^{\circ} 24^{\prime} 50.24^{\prime \prime N} ; 35^{\circ} 17^{\prime} 52.24^{\prime \prime} \mathrm{E}$} \\
\hline $5 . \mathrm{A}$ & April & 8.66 & $2430^{\mathrm{SS}}$ & 15.0 & 9 & & \\
\hline $5 . \mathrm{J}$ & July & 9.08 & $3040^{\mathrm{SS}}$ & 27.6 & 12 & & \\
\hline 5.0 & October & 9.33 & $546^{\mathrm{FW}}$ & 18.7 & 18 & & \\
\hline 5.D & December & 9.30 & $761^{\mathrm{FW}}$ & 5.2 & 1 & & \\
\hline 6 & Lake Söbe & & & & & \multirow[t]{5}{*}{1080} & \multirow[t]{5}{*}{$38^{\circ} 19^{\prime} 44.75^{\prime \prime} \mathrm{N} ; 35^{\circ} 17^{\prime} 20.00^{\prime \prime} \mathrm{E}$} \\
\hline $6 . \mathrm{A}$ & April & 7.78 & $880^{\mathrm{FW}}$ & 14.7 & 8 & & \\
\hline $6 . \mathrm{J}$ & July & 9.50 & $6780^{\mathrm{HS}}$ & 27.6 & 13 & & \\
\hline 6.0 & October & 9.83 & $472^{\mathrm{FW}}$ & 17.1 & 20 & & \\
\hline $6 . \mathrm{D}$ & December & 9.37 & $732^{\mathrm{FW}}$ & 5.2 & 4 & & \\
\hline 7 & Lake Camiz & & & & & \multirow[t]{5}{*}{1076} & \multirow[t]{5}{*}{$38^{\circ} 19^{\prime} 16.77^{\prime \prime} \mathrm{N} ; 35^{\circ} 19^{\prime} 27.71 " \mathrm{E}$} \\
\hline 7.A & April & 8.53 & $3520^{\mathrm{SS}}$ & 12.4 & 16 & & \\
\hline 7.J & July & 8.84 & $8780^{\mathrm{HS}}$ & 28.1 & 3 & & \\
\hline 7.0 & October & 9.28 & $1304^{\mathrm{SS}}$ & 17.7 & 3 & & \\
\hline 7.D & December & 9.12 & $1927^{\mathrm{SS}}$ & 5.2 & 5 & & \\
\hline 8 & Sultan Marshes & & & & & \multirow[t]{5}{*}{1075} & \multirow[t]{5}{*}{$38^{\circ} 16^{\prime} 20.60^{\prime \prime} \mathrm{N} ; 35^{\circ} 14^{\prime} 32.57^{\prime \prime} \mathrm{E}$} \\
\hline $8 . \mathrm{A}$ & April & 8.75 & $3270^{\mathrm{SS}}$ & 14.2 & 10 & & \\
\hline $8 . J$ & July & 8.48 & $8600^{\mathrm{HS}}$ & 30.4 & 1 & & \\
\hline 8.0 & October & 9.13 & $1293^{\mathrm{SS}}$ & 17.6 & 3 & & \\
\hline 8.D & December & 9.05 & $1679^{\mathrm{ss}}$ & 5.2 & 5 & & \\
\hline
\end{tabular}

packages/nlme/index.html), using square root transformation for the response variable. Model simplification was performed by model comparison maximizing the log-likelihood; we started with the most complex model, including all terms and interactions, and deleted the least significant interactions and terms one by one as far as a non-significant reduction in explanatory power was retained.

\subsection{Species composition}

We built a matrix of presence/absence of rotifer species for each of the 32 collections (four seasons for eight sampling sites), and we obtained a matrix of Jaccard indexes for all the pairwise comparison. We tested how differences in species composition (= Jaccard indexes) were affected by season, sampling site and environmental variables with an analysis of variance partitioning the total variance in the distance matrix, with the adonis algorithm in $R$ package vegan (http://cc.oulu.fi/ jarioksa/softhelp/vegan.html). The current version of the package does not allow controlling for random effects of repeated measures; thus, we included all variables, environmental variables, season of sampling and sampling site as fixed effects, and without testing for their interactions.

Distance between water bodies may affect species composition of rotifers. This hypothesis was investigated with a Mantel test between a matrix of Jaccard distances between overall species composition for each sampling site (merging data from all seasons), and a matrix of geographic distances between sampling sites. The test was one tailed since only a positive correlation is expected comparing geographical distances with species composition. Significance of the Pearson correlation coefficient was assessed in a randomization test with 1000 permutations. Geographic distances were calculated as the orthodromic distances (i.e., the minimum path on the Earth's surface) between the ponds (Imboden \& Imboden 1972).

\section{RESULTS}

Eighty-four species of Rotifera belonging to 32 genera were recorded (Tab. 2). 
Tab. 2. Presence (x) or absence (blank) of rotifer species for localities and months of collection (A, April; J, July; O, October; D, December).

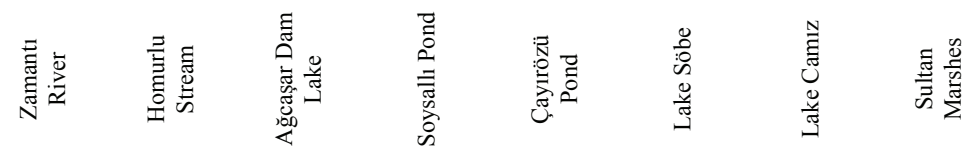

Anuraeopsis fissa Perty, 1850

Asplanchna priodonta Gosse, 1850

Brachionus angularis Gosse, 1851

B. calyciflorus Pallas, 1766

B. plicatilis Müller, 1786

B. quadridentatus Hermann, 1783

B. urceolaris Müller, 1773

Cephalodella catellina (Müller, 1786)

C. delicata Wulfert, 1937

C.cf. forceps Donner, 1950

C. forficula (Ehrenberg, 1830)

C. gibba (Ehrenberg, 1830)

C. misgurnus Wulfert, 1937

C. stenroosi Wulfert, 1937

C. sterea (Gosse, 1887)

C. ventripes (Dixon-Nuttall, 1901)

Colurella adriatica Ehrenberg, 1831

C. colurus (Ehrenberg, 1830)

C. obtusa (Gosse, 1886)

C. uncinata (Müller, 1773)

Dicranophoroides caudatus (Ehrenberg, 1834)

Dicranophorus grandis (Ehrenberg, 1832)

Dipleuchlanis propatula (Gosse, 1886)

Encentrum limicola Otto, 1936

E. mustela (Milne, 1885)

E. uncinatum (Milne, 1886)

Eosphora ehrenbergi Weber, 1918

Euchlanis dilatata Ehrenberg, 1832

E. incisa Carlin, 1939

Filinia terminalis (Plate, 1886)

Hexarthra fennica (Levander, 1892)

Itura intermedia Wulfert, 1935

Keratella cochlearis (Gosse, 1851)

K. quadrata (Müller, 1786)

K. tecta (Gosse, 1851)

K. tropica (Apstein, 1907)

Lecane bulla (Gosse, 1851)

L. closterocerca (Schmarda, 1859)

L. flexilis (Gosse, 1886)

L. furcata (Murray, 1913)

L. hamata (Stokes, 1896)

L. ludwigii (Eckstein, 1883)

L. luna (Müller, 1776)

L. lunaris (Ehrenberg, 1832)

L. nana (Murray, 1913)

L. papuana (Murray, 1913)

L. paradoxa (Steinecke, 1916)

L. pyriformis (Daday, 1905)

L. quadridentata (Ehrenberg, 1830)

L. cf. tenuiseta Harring, 1914

Lepadella biloba Hauer, 1958

L. ovalis (Müller, 1786)

L. patella (Müller, 1773)

L. quadricarinata (Stenroos, 1898)

L. rhomboides (Gosse, 1886)

L. triptera (Ehrenberg, 1832)

Lophocharis salpina (Ehrenberg, 1834)

Monommata dentata Wulfert, 1940

Mytilina mucronata (Müller, 1773)

M. ventralis (Ehrenberg, 1830)

M. bisulcata (Lucks, 1912)

Notholca acuminata (Ehrenberg, 1832)

$N$. squamula (Müller, 1786)

Paradicranophorus sordidus Donner, 1968

Platyias quadricornis (Ehrenberg, 1832)

Pleurotrocha petromyzon (Ehrenberg, 1830)

Polyarthra dolichoptera Idelson, 1925

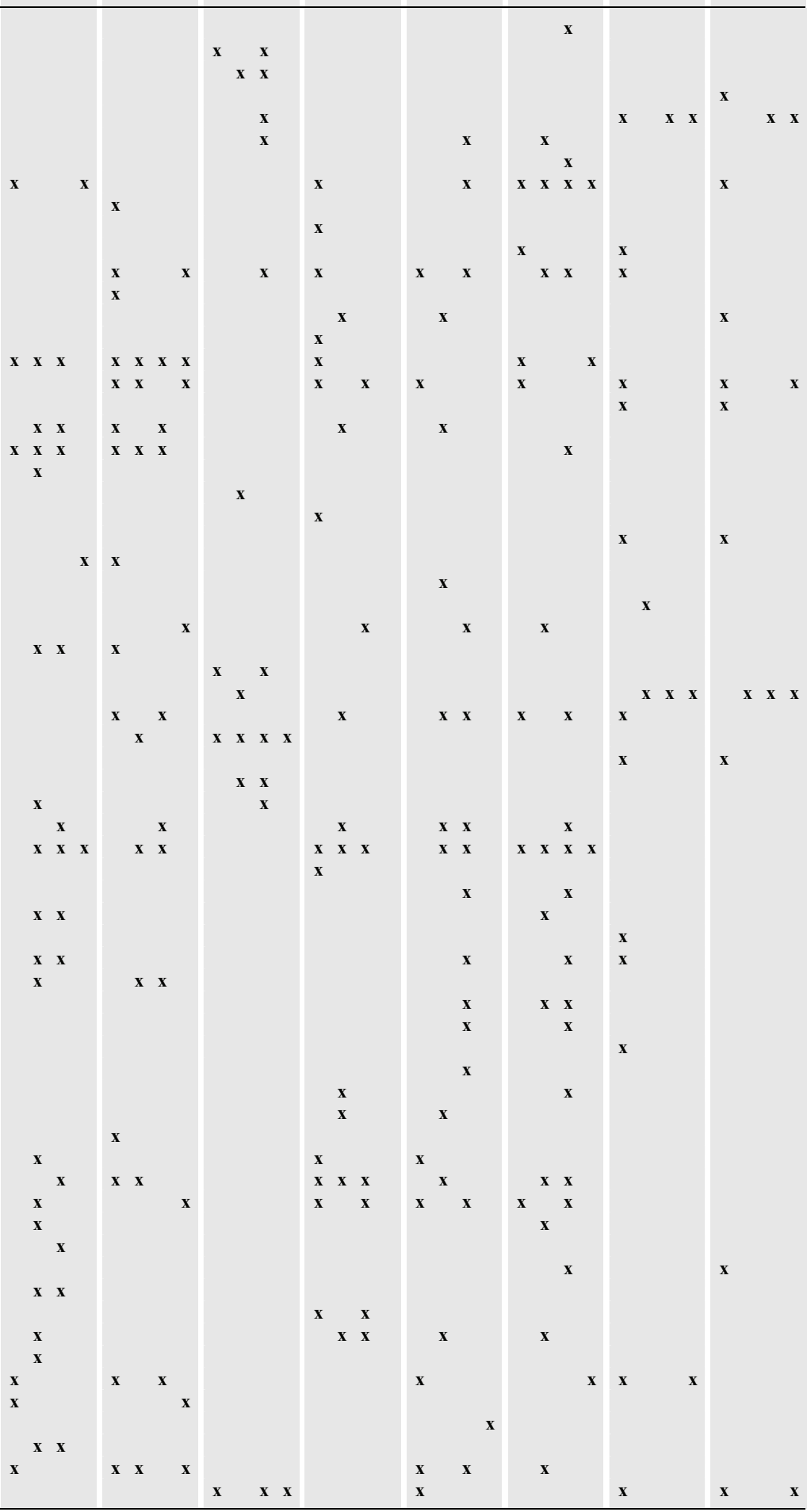

(continued) 
Tab. 2. Continuation.

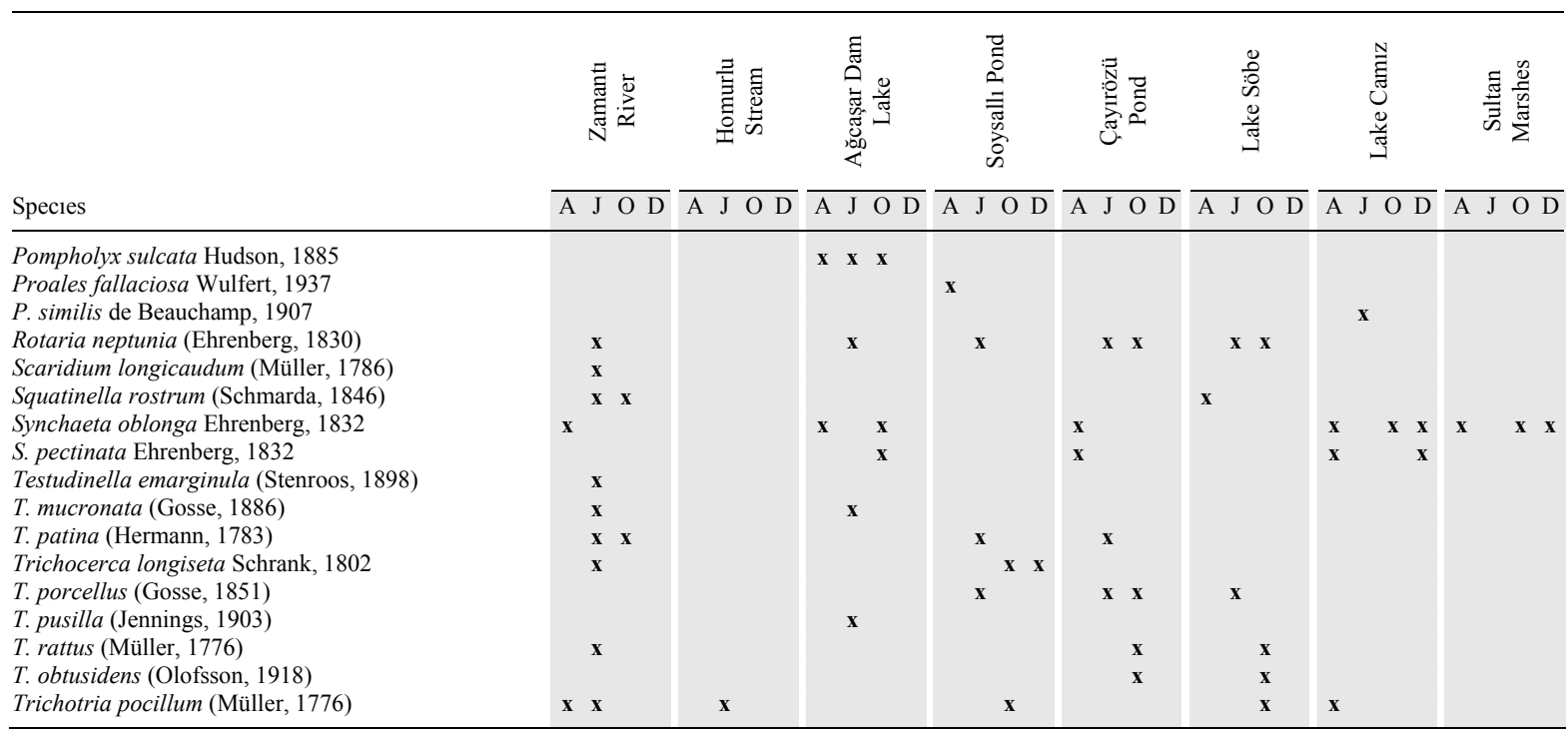

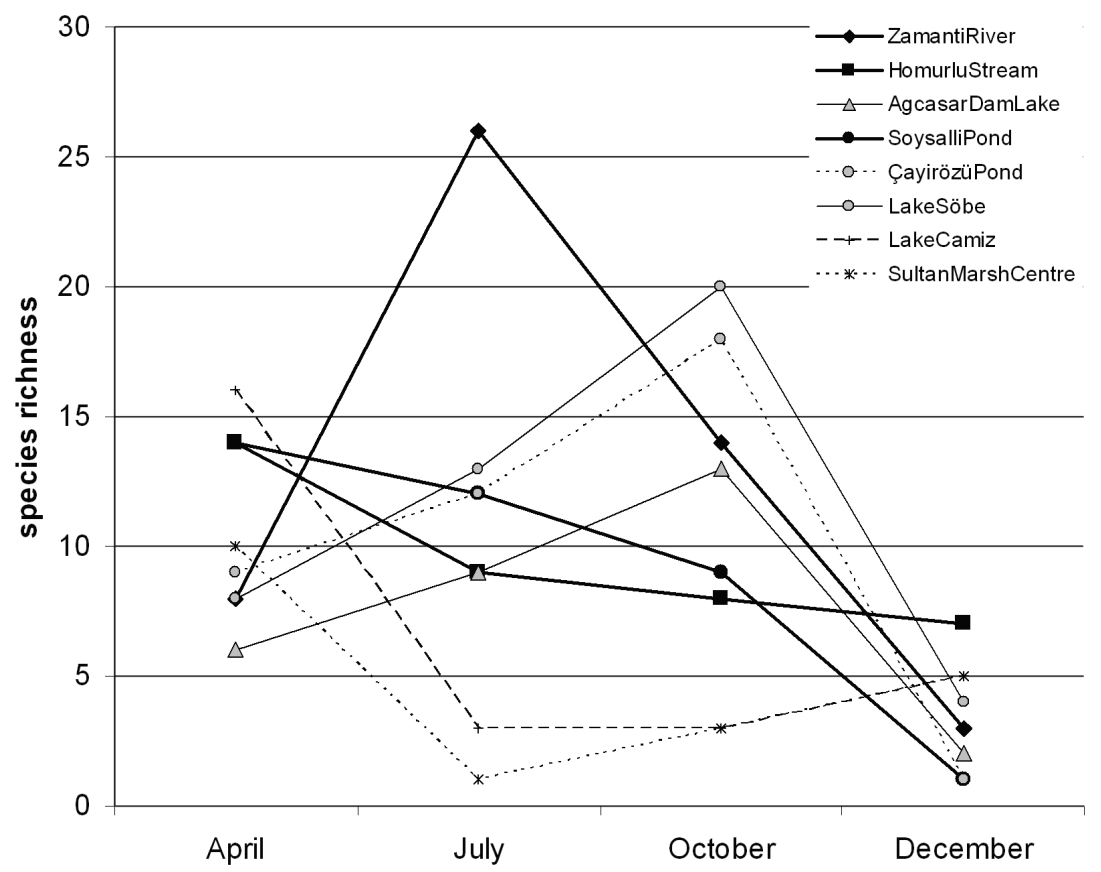

Fig. 2. Species richness of rotifers in the eight sampled water bodies in 4 different seasons. Strictly freshwater bodies are marked by thick lines and filled symbols, the other water bodies changed in their salinity during the seasons (see Tab. 1).

Of these, the majority (14 species, 16.6\%) belonged to the genus Lecane, followed by Cephalodella (9 species, 10.7\%), Lepadella (6 species, 7.1\%), Brachionus (5 species, 5.9\%) and Trichocerca (5 species, 5.9\%). Twenty-two of these species were observed only in one sample during the study.

\subsection{Species richness}

Overall species richness (Tab. 1, Fig. 2) was similar from April to October: 45 species were recorded in
April, 50 in July, and 52 in October. On the other hand, species richness was very low in December, with only 19 species. Species richness did not differ significantly between freshwater $(\mathrm{FW}$ : range $=1-26$, median $=9)$ and saline water habitats (SS + HS: range $=1-16$, median $=$ 6) (GLM: $p=0.205$ ). The highest species richness was reached in the freshwater Zamanti River in July; the other two permanently freshwater bodies (Homurlu Stream and Soysalli Pond) had richness decreasing from April to December; the saline systems had their maximum in October (Çayirözü Pond, Lake Söbe, and 
Ağcaşar Dam Lake) or in April (Lake Camiz and Sultan Marshes), (Fig. 2).

Due to possible confounding effects of other unmeasured environmental variables and of sampling sites, we tested the effect of measured environmental variables on species richness including sampling site as a random effect. The final model retained Temperature (T) and its interaction with Electrical Conductivity (EC) as significant (Tab. 3).

Tab. 3. Final model (Linear Mixed Effect Model for Repeated Measures), after simplification, explaining the effect of measured environmental variables $(\log \mathrm{L}$ $=-37.68 ; \mathrm{AIC}=87.36$ ).

\begin{tabular}{lccc}
\hline & d.f. & $t$-value & $P$ \\
\hline (Intercept) & 21 & 2.27 & 0.0337 \\
EC & 21 & 1.30 & 0.2063 \\
T & 21 & 4.29 & 0.0003 \\
EC:T & 21 & -2.42 & 0.0246 \\
\hline
\end{tabular}

Finally, to determine the effect of such interactions, we divided our results into three groups, according to salinity class: freshwater (FW), subsaline water (SS) and hyposaline water (HS) (Fig. 3). Performing the analyses separately for each salinity class, the final models retained temperature as the only significant factor affecting species richness in freshwater (LMEM: $t=5.56, p=0.0001$, sqrt(richness) $=0.851+0.174 \mathrm{~T}$ ), and electrical conductivity as the only significant factor in subsaline water (LMEM: $t=7.50, p=0.0007$, sqrt(richness) $=0.615+0.0009 \mathrm{EC})$. No analyses could be performed for hyposaline water, as only three datapoints were available; nevertheless, the two samples with the highest $\mathrm{EC}$, above $8000 \mu \mathrm{S} \mathrm{cm}^{-1}$, had the lowest species richness (Fig. 3).

\subsection{Species composition}

Most of the variability in species composition for each sample was due to random effects $(43 \%)$, and the only significant factor was sampling site, which accounted for $36 \%$ of the variability. Season of sampling was not significant, and differences in species composition related to environmental variables were negligible, always lower than $4 \%$ (Tab. 4). Thus, samples from the same water body are more similar in species composition to each other than to other samples, independently of the seasonal environmental changes.

Differences in the overall species composition for each water body were not related to geographic distances between samples (Mantel test: $R=0.081, p=$ $0.25)$.

Tab. 4. Results from the analysis of variance partitioning the total variance in the distance matrix of species composition.

\begin{tabular}{lcccc}
\hline & d.f. & F.Model & $R^{2}$ & $P$ \\
\hline water body & 7 & 2.15 & 0.364 & $<0.001$ \\
season & 3 & 1.72 & 0.123 & NS \\
T & 1 & 1.36 & 0.032 & NS \\
EC & 1 & 0.88 & 0.021 & NS \\
pH & 1 & 1.16 & 0.027 & NS \\
residuals & 17 & & 0.432 & \\
\hline
\end{tabular}

\section{DISCUSSION}

Temperature seems to be the main factor affecting species composition and richness of rotifers in freshwaters, while changes in salinity seem to over-ride this effect in the saline waters under study. Species composition is influenced mostly by sampling site and much less by season of sampling.

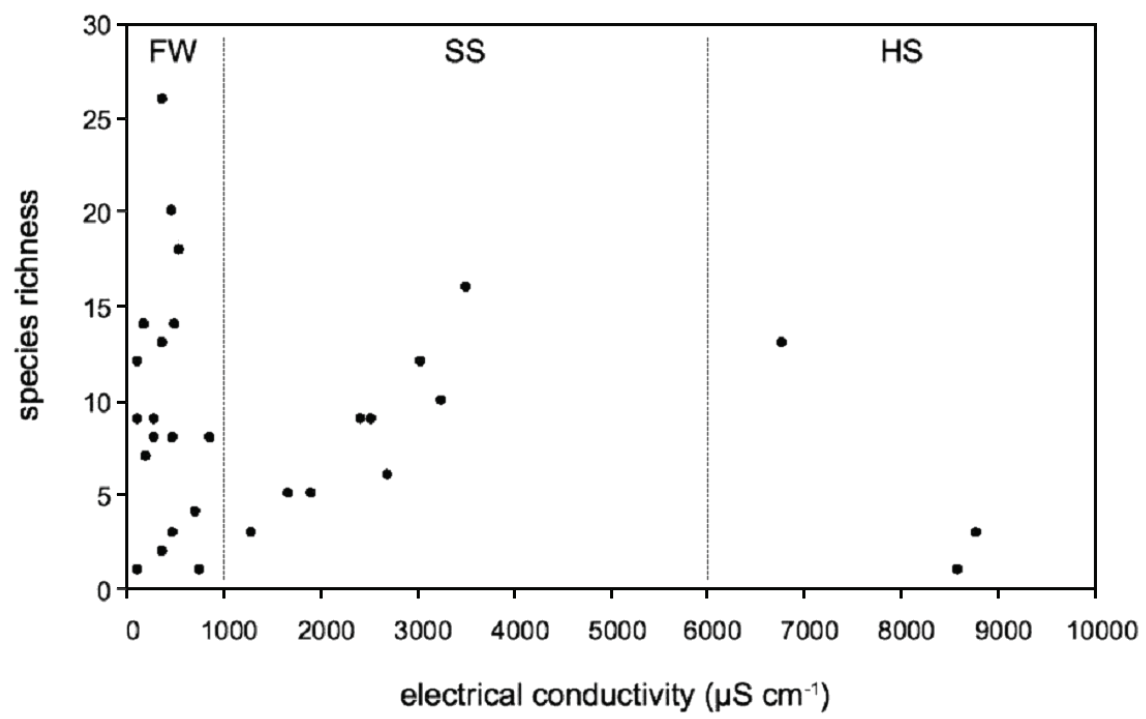

Fig. 3. Species richness in relation to electrical conductivity for each water body at the different sampling seasons. FW, freshwater; $\mathrm{SS}$, subsaline, HS, hyposaline water. 


\subsection{Species richness and salinity}

A general negative relationship was previously described between species richness and salinity (Hammer 1986; Lancaster \& Scudder 1987; Williams et al. 1990): significantly negative relationship in salinity ranges lower than $20,000 \mu \mathrm{S} \mathrm{cm}$, and negative but non-significantly for salinity higher than $20,000 \mu \mathrm{S}$ $\mathrm{cm}^{-1}$. Previous studies on rotifers in continental saltwater habitats confirmed such a relationship: many rotifers do not tolerate conductivities higher than $400 \mu \mathrm{S} \mathrm{cm}^{-1}$ (Kling et al. 1992), and Swadling et al. (2000) found significantly lower species richness between $700 \mu \mathrm{S}$ $\mathrm{cm}^{-1}$ and $1500 \mu \mathrm{S} \mathrm{cm}^{-1}$ than at conductivities below 700 $\mu \mathrm{S} \mathrm{cm}{ }^{-1}$. Species richness was also found to decrease with increasing salinity from 2800 to $50000 \mu \mathrm{S} \mathrm{cm}^{-1}$ (Egborge 1994). Planktonic rotifers in Turkish continental waters do not seem to conform to such general trends: (1) species richness of rotifers did not differ between fresh and subsaline waters, (2) after controlling for the effect of sampling site, no effect of salinity was present below $1000 \mu \mathrm{S} \mathrm{cm}^{-1}$, but an abrupt drop in species richness was present at the threshold between freshwater and subsaline waters; (3) unexpectedly, a significant positive relationship between species richness and salinity was present in subsaline waters (ranges between 1000 and $6000 \mu \mathrm{S} \mathrm{cm}^{-1}$ ) (Fig. 3). Thus, two thresholds were evident in the relationship between salinity and species richness, and they are perfectly overlapping with the thresholds proposed by Hammer et al. (1983) to divide salinity ranges for aquatic biota. Our study confirms the biological validity of such classification scheme for planktonic rotifers.

Thus, the relationship between species richness of planktonic rotifers and salinity may not be unequivocal as previously suggested. Nevertheless, we need to consider two caveats. First, the results may be limited to the peculiarities of inland Turkish waters, not supporting many typically saline rotifers. Actually, not many typically saline species were found; for example, Synchaeta and Notholca were each represented by 2 species only, while these genera are known to be generally more diverse in the plankton of saline systems (Fontaneto et al. 2006). Second, the results may be due to sampling artifacts and limited number of sampling sites, even if we tried to minimize these biases during the field sampling, collecting repeated samples from each locality and each season, and accounting for potential confounding effects in the analyses. Another problem could be due to the use of a plankton net $55 \mu \mathrm{m}$ pore sized, which is known to underestimate rotifer richness (Chick et al. 2010); nevertheless, there is no rationale to suggest differential sampling bias with different salinities.

\subsection{Species richness and temperature}

Parameters other than salinity may significantly affect species richness in inland waters (Williams 1998). A positive correlation between species richness and temperature is known (Matsubara 1993; Friberg et al. 2001; Castro et al. 2005; Hessen et al. 2007). In our study, species richness was positively affected by temperature only in proper freshwater. Thus, temperature seems to operate in two opposite directions: it is positively associated with species richness, as well as it positively affects salinity, as higher temperatures promote evaporation in inland water bodies, concentrating salts. Nevertheless, our results regarding temperature effects may be biased by the December samples, colder and with a lower number of species in all sites.

\subsection{Species composition}

Species composition is highly affected by sampling site for continental zooplankton (Shaw \& Kelso 1992; Walsh et al. 2007). Samples within the same water body generally tend to be more similar to each other than samples between water bodies. Our results are consistent with this spatial pattern: sampling site is the only significant variable explaining differences in species composition, accounting for $36 \%$ of the variability. Other confounding effects associated with water body were not measured in the analysis. Moreover, such strong influence of sampling site on species composition may mask the effect of environmental variables as salinity and temperature: our sampling strategy included eight water bodies only, which is a large enough sample size to analyze species richness, but to disentangle environmental effects on species composition, a much higher number of water bodies is needed.

\section{ACKNOWLEDGEMENTS}

This paper is a part of the first author's PhD thesis and supported by TÜBİTAK (107T922, TBAGHD363).

\section{REFERENCES}

Castro, B.B., S.C. Antunes, R. Pereira, A.M.V.M. Soares \& F. Gonçalves. 2005. Rotifer community structure in three shallow lakes: seasonal fluctuations and explanatory factors. Hydrobiologia, 543: 221-232.

Chick, J.H., A.P. Levchuk, K.A. Medley \& J.H. Havel. 2010. Underestimation of rotifer abundance a much greater problem than previously appreciated. Limnol. Oceanogr. Methods, 8: 79-87.

Cottenie, K., N. Nuytten, E. Michels \& L. De Meester. 2001. Zooplankton community structure and environmental conditions in a set of interconnected ponds. Hydrobiologia, 442: 339-350.

De Bie, T., S. Declerck, K. Martens, L. De Meester \& L. Brendonck. 2008. A comparative analysis of cladoceran communities from different water body types: patterns in community composition and diversity. Hydrobiologia, 597: 19-27.

De Smet, W.H. 1998. Preparation of rotifer trophi for light and scanning electron microscopy. Hydrobiologia, 387/388: 117-121.

Derry, A.M., E.E. Prepas \& P.D.N. Hebert. 2003. A comparison of zooplankton communities in saline lakewater with variable anion composition. Hydrobiologia, 505: 199-215. 
Dodson, S.I., A.L. Newman, S. Will-Wolf, M.L. Alexander, M.P. Woodford \& S. Van Egeren. 2009. The relationship between zooplankton community structure and lake characteristics in temperate lakes (Northern Wisconsin, USA). J. Plankton Res., 31: 93-100.

Duggan, I.C., J.D. Green \& R.J. Shiel. 2002. Distribution of rotifer assemblages in North Island, New Zealand, lakes: relationships to environmental and historical factors. Freshwat. Biol., 47: 195-206.

Egborge, A.B.M. 1994. Salinity and the distribution of rotifers in the Lagos Harbour- Badagry Creek system, Nigeria. Hydrobiologia, 272: 95-1004.

Fontaneto, D., W.H. De Smet \& C. Ricci. 2006. Rotifers in saltwater environments, re-evaluation of an inconspicuous taxon. Journal of the Marine Biological Association of the United Kingdom, 86: 623-656.

Fontaneto, D., W.H. De Smet, G. Melone. 2008. Identification key to the genera of marine rotifers worldwide. Meiofauna Marina, 16: 75-99.

Friberg, N., A.M. Milner, L.M. Svendsen, C. Lindegaard \& S.E. Larsen. 2001. Macroinvertebrate stream communities along regional and physico-chemical gradients in Western Greenland. Freshwat. Biol., 46: 1753-1764.

Hammer, U.T. 1986. Saline lake ecosystems of the world. Junk, Dordrecht: 616 pp.

Hammer, U.T., J. Shamess \& R.C. Hayness. 1983. The distribution and abundance of algae in saline lakes of Saskatchewan, Canada. Hydrobiologia, 105: 1-26.

Hart, C.M., M.R. González, E.P. Simpson \& S.H. Hurlbert. 1998. Salinity and fish effects on Salton Sea microecosystems: zooplankton and nekton. Hydrobiologia, 381: 129-152.

Hessen, D.O., V. Bakkestuen \& B. Walseng. 2007. Energy input and zooplankton species richness. Ecography, 30: 749-758.

Imboden, C. \& D. Imboden. 1972. Formel fur Orthodrome und Loxodrome bei der Berechnung von Richtung und Distanz zwischen Beringungs- und Wiederfundort. Vogelwarte, 26: 336-346.

Jeppesen, E., J.P. Jensen, M. Søndergaard, T. Lauridsen \& F. Landkildehus. 2000. Trophic structure, species richness and biodiversity in Danish lakes: changes along a phosphorus gradient. Freshwat. Biol., 45: 201-218.

Kaya, M. \& A. Altındağ. 2007. Zooplankton fauna and seasonal changes of Gelingüllü Dam Lake (Yozgat, Turkey). Turk. J. Zool., 31: 347-351.

Kling, G.W., W.J. O'Brien, M.C. Miller \& A.E. Hershey. 1992. The biochemistry and zoogeography of lakes and rivers in artic Alaska. Hydrobiologia, 240: 1-14.

Lancaster, J. \& G.G.E. Scudder. 1987. Aquatic Coleoptera and Hemiphera in some Canadian saline lakes: patterns in community structure. Can. J. Zool., 75: 1383-1390.

Matsubara, T. 1993. Rotifer community structure in the south basin of Lake Biwa. Hydrobiologia, 271: 1-10.

Muirhead, J.R., J. Ejsmont-Karabin \& H.J. Macisaac. 2006. Quantifying rotifer species richness in temperate lakes. Freshwat. Biol., 51: 1696-1709.

Received: April 2010

Accepted: May 2010
R Development Core Team, 2007. R: A Language and Environment for Statistical Computing. R Foundation for Statistical Computing, Vienna. http://www.R-project.org.

Schallenberg, M., C.J. Hall \& C.W. Burns. 2003. Consequences of climate induced salinity increases on zooplankton abundance and diversity in coastal lakes. Mar. Ecol. Prog. Ser., 251: 181-189.

Segers, H. 2004. Rotifera Monogononta. In: Yule C.M. \& Yong H.S. (Eds), Freshwater invertebrates of the Malaysia Region. Academy of Sciences and Monash University, Malaysia, Kuala Lumpur: 112-116 pp.

Segers, H. 2007. Annotated checklist of the rotifers (Phylum Rotifera) with notes on nomenclature, taxonomy and distribution. Zootaxa, 1564: 1-104.

Segers, H. \& H.J. Dumont. 1995. 102+ rotifer species (Rotifera: Monogononta) in Broa reservoir (SP, Brazil) on 26 August 1994, with the description of three new species. Hydrobiologia, 316: 183-197.

Shaw, M.A. \& J.R.M. Kelso. 1992. Environmental factors influencing zooplankton species composition of lakes in north-central Ontario, Canada. Hydrobiologia, 241: 141-154.

Shiel, R.J., J.F. Costelloe, J.R.W. Reid, P. Hudson \& J. Powling. 2006. Zooplankton diversity and assemblages in arid zone rivers of the Lake Eyre Basin, Australia. Marine and Freshwat. Res., 57: 49-60.

Swadling, K.M., R. Pienitz \& T. Nogrady. 2000. Zooplankton community composition of lakes in the Yukon and Northwest Territories (Canada): relationship with physical and chemical limnology. Hydrobiologia, 431: 211-224.

Toumi, N., H. Ayadi, O. Abid, J. Carrias, T. Sime-Ngando, M. Boukhris \& A. Bouain. 2005. Zooplankton distribution in four ponds of different salinity: a seasonal study in the solar salterns of Sfax (Tunisia). Hydrobiologia, 534: 1-9.

Wallace, R.L., T.W. Snell, C. Ricci \& T. Nogrady. 2006. Rotifera: Volume 1 Biology, Ecology and Systematics (2nd ed.). In: Segers, H. \& H.J. Dumont (Eds), Guides to the identification of the microinvertebrates of the continental waters of the world. Vol. 23. Kenobi Productions, Ghent, and Backhuys Publishers, Leiden: 299 pp.

Walsh, E.J., T. Schröder, M.L. Arroyo \& R.L. Wallace. 2007. How well the single samples reflect rotifer species diversity? A test based on interannual variation of rotifer communities in Big Bend National Park (Texas, USA). Hydrobiologia, 593: 39-47.

Walsh, E.J., T. Schröder, R.L. Wallace, J.V. Ríos-Arana \& R. Rico-Martínez. 2008. Rotifers from selected inland saline waters in the Chihuahuan Desert of México. Saline Systems, 4(7): 11 pp.

Williams, W.D. 1998. Salinity as a determinant of structure of biological communities in salt lakes. Hydrobiologia, 381: 191-201.

Williams, W.D., A.J. Boulton \& R.G. Taaffe. 1990. Salinity as a determinant of salt lake fauna: a question of scale. Hydrobiologia, 197: 257-266. 